Vol. 6, No. 1, 2019

https://doi.org/10.23939/eem2019.01.070

UDC 168.522:339.138

JEL Classification C51, F15, L11

O. Karyy

Lviv Polytechnic National University, Ukraine, Doctor, Professor

\author{
K. Protsak
}

Lviv Polytechnic National University, Ukraine, PhD, Associate Professor

O. Prosovych

Lviv Polytechnic National University, Ukraine, PhD, Associate Professor

\title{
MARKETING COMMUNICATIONS AS A NECESSARY PREREQUISITE FOR EFFICIENT WORK OF A PHILHARMONY
}

\begin{abstract}
The purpose of the article is to summarize the peculiarities of marketing communications in the field of culture and arts and philharmonic in particular, to consider the financial component of the activities of the philharmonic and to propose measures for its improvement. Analyze modern creative means and tools of communication marketing and adapt them for activities of philharmonic. The article investigates that organizations of the sphere of culture and arts and philharmonic society, in particular, operate in conditions of instability, great competition and uncertainty. Their success depends directly on the number of visitors. Therefore, marketing communications play an extremely important role in the life of cultural and arts organizations and the philharmonic. In general, the marketing of organizations of the socio-cultural sphere and the philharmonic, in particular, consists of the same components - good, price, place and promotion, but in the philharmonic they have their own specific, which is that the product can be divided into the main and the additional. It is also noted that the implementation of philharmonic events non-commercial and commercial marketing leads to the same effects - a high commercial outcome. The difficulty in promoting of philharmonic arts services is due to lack of funds for such events. In order to realize marketing measures of a flexible strategy of cultural and arts organization, it is proposed to implement the latest financial technologies fundraising and crowdfunding. Elements of scientific novelty can see in construction of an algorithm of action in the application of fundraising, as well as in generalization of modern types of marketing
\end{abstract}

communications tools for the philharmonic. The practical value of this study is to elaborate on the application of four possible to promote the future of the Philharmonic\&\#39; s concert, namely EventMarketing, Art-Marketing, Entertainment Marketing and Guerrilla Marketing. The advantages, disadvantages and costs of each of these promotion methods are outlined. The research found that Guerrilla marketing or Art-marketing is inappropriate due to its quot; aggressive\&quot; way of promoting and possible problems with obtaining permission, while Entertainment-marketing and Event marketing are recommended for use in the Philharmonic. Also the main stages of the use of Event-marketing are described in detail. It is recommended to borrow foreign experience. For the Philharmonic, it is suggested to use the experience of the world class chamber orchestra of Manchester Kamerata. This orchestra promotes its cultural product very flexible and attract the maximum number of viewers. Further research will address the more detailed study of the effectiveness of marketing activities of the cultural and arts organizations.

Key words: marketing communications, fundraising, crowdfunding, marketing tools, philharmonics.

\section{Problem statement in general form}

At the present stage of development of society, marketing is effectively used not only in business, but also in the field of non-profit organizations, including cultural and artistic institutions. Marketing technologies play an 
increasingly important role in the development of modern socio-cultural processes. Theatres, concert halls, philharmonics, museums, galleries and other socio-cultural institutions actively vie for the consumer, competing by using cable and satellite television, sports broadcasts, a huge range of entertainment industries (from shows to gaming machines), the Internet, social networks, alternative educational and entertaining practices etc. Modern cultural and artistic organizations also face the problem of limited budget financing, so they should learn how to attract additional financial resources and use them with maximum benefit.

\section{Analysis of recent sources and publications}

Marketing research in Ukraine started in the 90s of the last century, and since then has been actively developed by domestic scientists. However, there are not very many research works devoted to the peculiarities of marketing in the field of culture and arts.

In 1967, for the first time in history, F. Kotler raised the idea of using marketing in the field of culture and arts. In his famous book, he pointed out that all cultural organizations, whether they being museums, libraries or concert halls, produce cultural goods. In other writings he emphasized the peculiarities of the promotion of this kind of goods and the ways to compete for the consumer in this field [1]. The well-known works of Mokv, Reis, Diggles, Colber are dedicated to the study of marketing in the field of culture and arts [2].

In her works Borisova T. M. researched features of marketing in the social sphere [3]. Her works are devoted to specifying the economic and social prerequisites of implementing marketing in domestic social sphere, to determining the areas of marketing activities of non-commercial entities, in particular, in the sphere of culture and arts.

Domestic scholars also explore some aspects of the marketing activities of organizations in the field of culture and arts. For example, Larina A. V. examines peculiarities of the cultural product promotion of [5.]. In other works [8], more attention is paid to tools for promoting the cultural product in the Internet. Some scholars suggest applying some marketing categories taking into account the specifics of the field of culture and arts $[4,8]$. Kuchyna N. I. investigates the role of marketing in the activities of organizations of the socio-cultural sphere through the prism of main marketing categories: consumer, product, price and communication [4]. The recommendations for improving the marketing activities of cultural organizations in Ukraine, following the experience of foreign countries and the modern trends in the development of communication tools, are presented in [8] and deserve attention. The features of informational, non-commercial marketing and marketing communications, the possibility of increasing sales of cultural products through their advertising and promotion in the information space are presented in the work of Stepanov V. Y. [9].

However, marketing issues in the field of culture and arts remain poorly developed and require more detailed research.

The purpose of the article is to summarize peculiarities of marketing communications in the field of culture and arts (the case of philharmonics); to consider the financial component of the activities of the philharmonic and to propose measures for its improvement; to analyse modern creative tools and instruments of marketing communications and adapt them to philharmonic activities.

\section{The main material}

The modern sphere of culture and arts in Ukraine functions in conditions of considerable instability, connected with financial and political crises, military actions in Donbass and the annexation of the Crimea. But despite this, the number of cultural and artistic institutions has not decreased in recent years (Table 1). The same cannot be said about the number of people who attended the events at these institutions. So, starting from 2014, the number of viewers of theatre performances decreased, in average, by $18 \%$, listeners at concerts - by $45 \%$, and visitors of museums - by $32 \%$.

Let us start with considering the main features of marketing of organizations in the field of culture and arts, which are summarized in Table 2. 
Provision of population with cultural and arts institutions in Ukraine in 2010-2016

\begin{tabular}{|c|c|c|c|c|c|c|c|}
\hline & 2010 & 2011 & 2012 & 2013 & $2014^{* *}$ & $2015^{* *}$ & $2016^{* *}$ \\
\hline Population, thousand people & 45962.9 & 45778.5 & 45633.6 & 45553.0 & 45426.2 & 42760.5 & 42584.5 \\
\hline Number of theatres, units & 140 & 133 & 132 & 133 & 113 & 113 & 112 \\
\hline $\begin{array}{c}\text { Number of theatres } \\
\text { units per 1 million people) }\end{array}$ & 3.05 & 2.91 & 2.89 & 2.92 & 2.49 & 2.64 & 2.63 \\
\hline $\begin{array}{c}\text { Number of viewers at } \\
\text { performances, } \\
\text { million people }\end{array}$ & 6.6 & 6.7 & 6.7 & 6.9 & 5.4 & 5.6 & 5.8 \\
\hline $\begin{array}{c}\text { Number of concert } \\
\text { organizations, units }\end{array}$ & 83 & 82 & 88 & 85 & 73 & 73 & 76 \\
\hline $\begin{array}{c}\text { Number of concert organizations } \\
\text { (units per }\end{array}$ & 1.81 & 1.79 & 1.93 & 1.87 & 1.61 & 1.71 & 1.78 \\
\hline $\begin{array}{c}\text { Number of listeners at concerts } \\
\text { (millions of people) }\end{array}$ & 4.2 & 4.1 & 4.6 & 4.6 & 2.4 & 2.5 & 2.6 \\
\hline Number of museums, units & 546 & 570 & 592 & 608 & 543 & 564 & 576 \\
\hline $\begin{array}{c}\text { Number of museums (units per } \\
1 \text { million people) }\end{array}$ & 11.88 & 12.45 & 12.97 & 13.35 & 11.95 & 13.19 & 13.53 \\
\hline $\begin{array}{c}\text { Number of visitors to museums, } \\
\text { (millions of people) }\end{array}$ & 21.7 & 21.8 & 22.4 & 22.3 & 14.2 & 15.1 & 15.8 \\
\hline
\end{tabular}

Source: based on [11].

** Without consideration of the temporarily occupied territory of the Autonomous Republic of Crimea, the city of Sevastopol and the parts of Donetsk and Luhansk regions

The main features of marketing of organizations in the field of culture and arts

Table 2

\begin{tabular}{|c|c|c|c|}
\hline № & Feature & Description & Implementation problems \\
\hline 1 & 2 & 3 & 4 \\
\hline 1 & $\begin{array}{l}\text { Specificity of the } \\
\text { cultural good } \\
\text { (service) of cultural } \\
\text { and artistic } \\
\text { organizations }\end{array}$ & $\begin{array}{l}\text { The peculiarity lies in the fact } \\
\text { that there is sold the product of } \\
\text { collective creativity of specialists } \\
\text { and at the same time, the } \\
\text { aesthetic and spiritual } \\
\text { development of the personality is } \\
\text { provided }\end{array}$ & $\begin{array}{l}\text { The industrial products produced and used by } \\
\text { cultural organizations (technical equipment, musical } \\
\text { instruments, transport) are qualified in this case as } \\
\text { tools. This frees organizations of culture from the } \\
\text { burden of developing such products and allows them } \\
\text { to concentrate on the production of their "specific } \\
\text { goods": performances, concerts, exhibitions, films } \\
\text { and other cultural products. }\end{array}$ \\
\hline 2 & $\begin{array}{l}\text { The predominance of } \\
\text { non-profit marketing } \\
\text { that does not pursue } \\
\text { the purpose to make } \\
\text { profit }\end{array}$ & $\begin{array}{l}\text { The main thing is satisfaction of } \\
\text { cultural needs of different layers } \\
\text { and groups of consumers, and not } \\
\text { profit making by any methods }\end{array}$ & $\begin{array}{l}\text { The management of such organisations think } \\
\text { about the artistic and educational aspects of } \\
\text { professional activities, and usually has no } \\
\text { experience in attracting financial resources thus } \\
\text { having problems with the implementation of } \\
\text { artistic projects, opportunities to tour etc. }\end{array}$ \\
\hline 3 & $\begin{array}{l}\text { The dominant } \\
\text { advantage is talented } \\
\text { and skilled staff }\end{array}$ & $\begin{array}{l}\text { The success of such organizations } \\
\text { depends first of all on the talent and } \\
\text { professionalism of the masters of } \\
\text { culture and arts. In this regard, } \\
\text { particular attention should be paid to } \\
\text { the marketing of a personality }\end{array}$ & $\begin{array}{l}\text { The manager is responsible for correct selection, } \\
\text { training, professional and personal development } \\
\text { as well as motivation of creative employees. } \\
\text { There is a threat of the outflow of gifted youth } \\
\text { abroad }\end{array}$ \\
\hline
\end{tabular}


Table 2 continuation

\begin{tabular}{|c|c|c|c|}
\hline 1 & 2 & 3 & 4 \\
\hline 4. & $\begin{array}{l}\text { The social mission is } \\
\text { to form the stratum } \\
\text { of intelligentsia, to } \\
\text { develop tastes in } \\
\text { culture and arts, and } \\
\text { to engage the new } \\
\text { generation of young } \\
\text { people }\end{array}$ & $\begin{array}{l}\text { The social mission of cultural } \\
\text { and artistic organizations obliges } \\
\text { them not only to follow the } \\
\text { today's needs of the public, but } \\
\text { also to purposefully form them, } \\
\text { to engage in enlightenment, } \\
\text { upbringing and development of } \\
\text { the individual }\end{array}$ & $\begin{array}{l}\text { The impact of modern information and } \\
\text { communication technologies requires changes in } \\
\text { the activities of cultural and artistic } \\
\text { organizations, makes them go beyond the } \\
\text { traditional concert performances, adapt to the } \\
\text { virtual sound and visual space created by } \\
\text { electronic media and the Internet etc }\end{array}$ \\
\hline & $\begin{array}{l}\text { The importance of } \\
\text { establishing links } \\
\text { with the internal and } \\
\text { external marketing } \\
\text { environment }\end{array}$ & $\begin{array}{l}\text { A necessary condition for the } \\
\text { productive work of organizations } \\
\text { of the socio-cultural sphere is } \\
\text { their broad and diverse ties with } \\
\text { political, scientific, pedagogical, } \\
\text { law enforcement, economic, and } \\
\text { business spheres }\end{array}$ & $\begin{array}{l}\text { The wider and more stable these contacts are, the } \\
\text { more diverse is the activity of the organization of } \\
\text { culture, the stronger is its position in society, the } \\
\text { more successfully it performs its functions and } \\
\text { realizes its social mission. Though it is not } \\
\text { always easy }\end{array}$ \\
\hline
\end{tabular}

Source: composed on the basis of [1]

The information in Table 2 allows to highlight the important role of marketing for organizations in the field of culture and arts and to trace its main differences from the classical marketing of services for commercial organisations.

First of all, this is the difference in purpose: the commercial firm is looking for a market where it is possible to achieve the optimum profit, otherwise it will abandon the market due to lack of consumer interest while the cultural and artistic organization is primarily focused on art, rather than profit. However, the recognition of art (of an artist, singer, actor etc.) leads to increased attendance of artistic events and, consequently, to financial success as well. Thus, implementation of successful measures of both non-commercial and commercial marketing leads to the same effect $-\mathrm{a}$ high financial outcome. Abroad, commercial marketing is an important component of the artistic events management, and the art in its vast majority is considered as business, mainly show business.

In general, the marketing of organizations of the socio-cultural sphere and the philharmonic, in particular, consists of the same components product, price, place and promotion, but in the philharmonic they have their own specifics. The product itself can be divided into primary and secondary. The main "cultural product" of the philharmonic is holding concerts, festivals, performances and the like. In addition, the philharmonic can offer secondary products and services. These may include, for example:

a) conducting concerts of artistic groups and soloists both in the premises of the artistic organization and in the organization that orders the event. It is possible to order both a joint concert and a concert of a separate artistic group or soloist;

b) organising workshops, studios, including children's, master classes etc.;

c) ordering concerts of Ukrainian pop stars at customer's request;

d) providing services, the assortment of which is determined by the capabilities of the organisation's staff and infrastructure;

e) writing the event's script, texts, music, phonograms and arrangement of works for the above-mentioned events;

f) arranging professional sounding and lighting, projection systems, fireworks, festive design of the event;

g) providing high-quality and particular souvenirs, for example, with the brand name of the artistic organization;

h) providing books, catalogues, booklets and other printing products either directly dealing with the theme of the repertoire of the cultural and artistic organization or on similar subjects, as well as video films, slides, CD-ROMs and other products that use modern information technologies;

i) leasing the premises of the cultural and artistic organization. 


\section{O. Karyy, K. Protsak, O. Prosovych}

In addition, the main products and services as well as most of the additional products and services provided by an artistic organization are of great importance for and have influence on the formation of the corresponding culture and consciousness of potential visitors who would learn to understand a certain type of art, would receive aesthetic pleasure and positive emotions. Unfortunately, the lack of free time and low purchasing power of most potential spectators, of course, have a negative impact on the consumption of cultural and artistic services.

The promotion of cultural and art products has the following objectives:

1) to provide information (to help the consumer learn about the existence of the product (service), to inform about the time and place of the performance or concert, the way of purchasing tickets);

2) to persuade ("to convince consumers to buy a product by offering additional motivations, namely: the quality of performance, the participation of famous star performers, the uniqueness of the program, accessibility, social prestige or public recognition, enrichment of experience");

3) to educate ("to provide consumers with means and a system of criteria and values necessary for the evaluation of product features" [5]).

Obviously, these three specified objectives correspond to three key functions and goals of promotion: informational, axiological and interpretative, respectively.

Therefore, it is necessary to deliberately and carefully form a repertoire of a philharmonic and to systematically and comprehensively build a strategy of interaction with existing and potential consumers, partners, sponsors, local government and state authorities.

The difficulty in promoting the philharmonic art services occurs due to lack of financing for such events. Most organizations of culture and arts belong to communal property and are financed from regional or city budgets. However, this financing covers only part of the protected expenditures - wages and utilities. The rest should be covered by the organizations' own funds.

The main purpose of cultural and artistic organizations, as has already been mentioned above, is not to get profit, but to provide spiritual satisfaction to visitors, to increase the prestige of the institution of culture and arts. Taking into account the fact that in the national cultural and art institutions managerial positions are occupied mainly by people with art education who have neither knowledge nor experience of doing business, self-financing of such organizations seems to be rather problematic. The optimization of forms of cooperation of the cultural and artistic organization with its creative and business partners, sponsors, foundations, local self-government bodies and state authorities can help realize their creative plans.

As a rule, it cannot be foreseen in advance how much funding can be attracted through such cooperation with sponsors and partners, therefore, it is suggested for such organizations to plan a flexible budget. Flexible strategy is based on the fact that the amount of additional sponsorship and the amount of revenue from the sale of services are the forecast values, rather than the fixed ones. Consequently, the organization creates a flexible budget, which is based on the principle of priority of socially and culturally important tasks. This means that the available funds are spent in the order of task priority: less important tasks are financed only after sufficient financing of more important tasks (Table 3).

To implement philharmonic marketing activities, we also propose to use the latest financial technologies of fundraising and crowdfunding.

In a broad sense, under fundraising one can understand the process of finding and attracting resources for different purposes that are relevant in the modern domestic economic environment. Fundraising in culture is aimed at providing financial support in the field of painting and music, literature, theatres, cinema, museums, libraries.

The main motivations for business representatives to direct funds for cultural development are:

- advertising opportunities (promotion of a brand or company's products) within the framework of a cultural project;

- creation of a positive image of the company, demonstration of the policy of social responsibility;

- access to the target audience within the framework of an art event to promote their own products / services [13].

At the heart of the proper construction of fundraising is the approach, which involves the following algorithm of actions (Fig. 1). 
Ranking philharmonic activities depending on the sources of funding

\begin{tabular}{|c|l|l|l|}
\hline Group & \multicolumn{1}{|c|}{ The nature of the activity } & \multicolumn{1}{c|}{ Content } & \multicolumn{1}{c|}{ Sources of funding } \\
\hline A & $\begin{array}{l}\text { Activity is mandatory in the } \\
\text { reporting period }\end{array}$ & $\begin{array}{l}\text { Staging the main repertoire, salary } \\
\text { of workers, utility payments }\end{array}$ & $\begin{array}{l}\text { Mandatory receipts (from } \\
\text { state or local governments) }\end{array}$ \\
\hline B & $\begin{array}{l}\text { Projects, the realization of which is } \\
\text { possible with the appearance of targeted } \\
\text { financing and (or) free funds attracted } \\
\text { by the organization, while their } \\
\text { implementation is highly desirable }\end{array}$ & $\begin{array}{l}\text { New productions, special events } \\
\text { (concerts of world stars, international } \\
\text { festivals), restoration of premises and } \\
\text { modernization of equipment, } \\
\text { renovation of old productions }\end{array}$ & $\begin{array}{l}\text { Income from own activity; } \\
\text { additional government } \\
\text { funding; funds from big } \\
\text { sponsors }\end{array}$ \\
\hline C & $\begin{array}{l}\text { Large-scale projects, the realization } \\
\text { of which is possible only with the } \\
\text { involvement of significant } \\
\text { extrabudgetary funds }\end{array}$ & $\begin{array}{l}\text { International tours of the } \\
\text { collective, festivals, master classes } \\
\text { of foreign stars }\end{array}$ & $\begin{array}{l}\text { Provided with support from } \\
\text { major sponsors }\end{array}$ \\
\hline D & $\begin{array}{l}\text { Small projects, the realization of } \\
\text { which can be fully funded by } \\
\text { sponsors }\end{array}$ & $\begin{array}{l}\text { Purchase of instruments for } \\
\text { orchestra, modernization of separate } \\
\text { sectors, production of printed } \\
\text { materials, implementation of } \\
\text { educational and children's programs. }\end{array}$ & $\begin{array}{l}\text { Provided by means of small } \\
\text { charitable contributions }\end{array}$ \\
\hline
\end{tabular}

Source: compiled on the basis of [14]

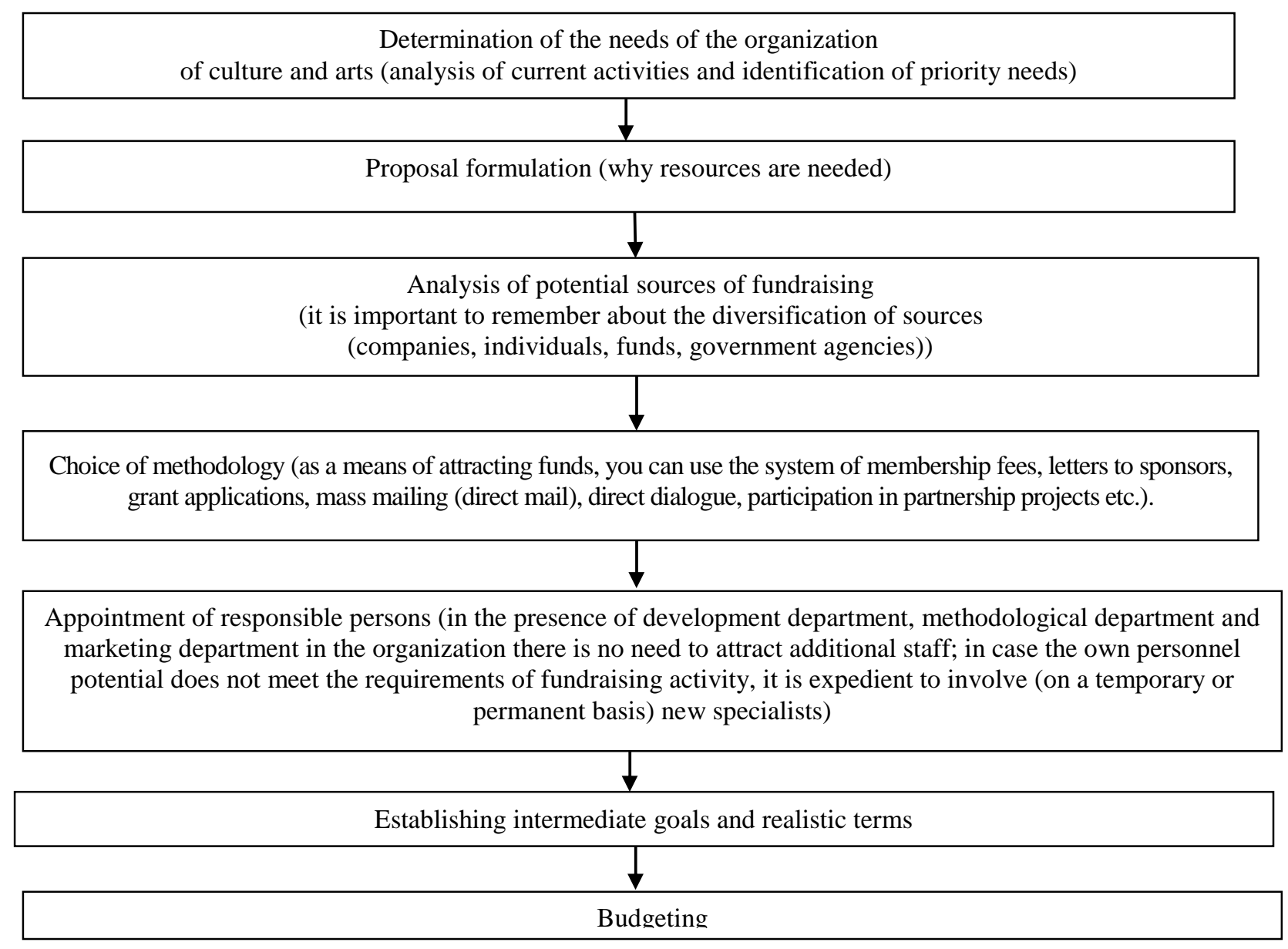

Fig. 1. Application of fundraising by cultural and artistic organizations in order to attract additional funds Source: compiled on the basis of [13] 


\section{O. Karyy, K. Protsak, O. Prosovych}

As to attracting financial resources through the Internet, the method of crowdfunding has proven to be successful. Crowdfunding refers to the cooperation of people who voluntarily invest money or other resources through the Internet to support a specific project.

Funding under this scheme can be used for organising children's competitions and providing support for gifted young people, organizing charity concerts for raising funds for the sick, warwounded, the army.

This financing is carried out in three models [3]:

- a donation model (the funds are contributed without expectation of any financial returns from the given contribution, but a small reward is possible: e.g. branded gifts and souvenirs);

- a model of crediting (typical lending, from which the return of the invested money or receipt of the finished product / service) is expected;

- an investment model (investment of funds that involves participating in project management through securities or receiving a share of profit from a project).

The first model, the donation model, is the most widespread and most suitable for implementing public and arts projects of a philharmonic. Upon completion of the project, all potential investors should be happy with the feeling of helping a good deed and see material or other evidence of the effectiveness of the invested funds.

Crowdfunding projects develop like viruses: without the presence of a proper marketing strategy their future is unpredictable. There is a large number of sites that allow you to tell the public about your project and collect the necessary amount of money. One of the most successful among the Ukrainian crowdfunding platforms is "Big idea", which has been successfully operating since 2012.

It is believed that the principle of "every little bit helps", which is embodied in crowdfunding, helps to find alternative financing for projects in both non-profit and commercial sectors. It is quite popular in times of crisis and can be successfully implemented by cultural and artistic organizations [12, p. 30].

The success of cultural and artistic organizations depends to a large extent on the number of visitors. For many potential visitors to learn about a particular artistic event and to express a desire to visit it, effective advertising is needed. That is why with each passing year interest in new approaches of creative advertising grows. This tendency is caused by the fact that the price of standard (ordinary) advertising (television, radio, printed products etc.) increases every year, and its effectiveness, on the contrary, decreases (potential consumers are irritated when they are handed in promotional products, they switch channels when advertising is shown etc). F. Kotler noted that innovation is the key and foundation of modern competitive strategies [1]. The only way to attract attention of consumers is novelty, that is, the use of creative means and tools of marketing communications. Examples of such modern types of marketing communications tools are shown in Fig. 2.

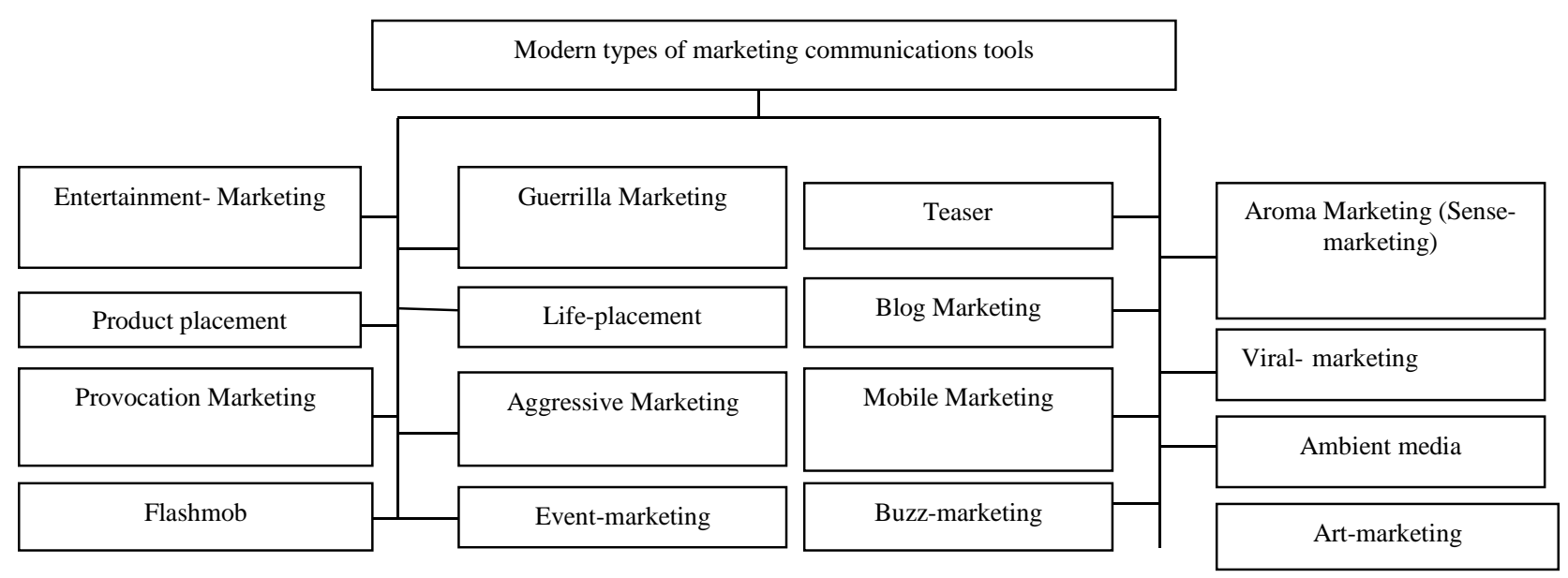

Source: based on $[15,16]$ 
From the above list, let us look at some of the types of innovative marketing communications that can be applied to cultural and artistic organizations illustrated by the philharmonic. Table 4 presents some of the contemporary creative types of marketing communications, their positive and negative aspects, as well as specific examples of applications for the philharmonic.

Having considered four possible ways of creative promotion of the future concert, we clarified that Event-marketing, Art-marketing, and
Entertainment-marketing will be the most accessible and affordable.

Guerrilla marketing and Art-marketing are not suitable because of their "aggressive" way of promotion and possible problems with obtaining permission, while Entertainment-marketing and Event-marketing are recommended for use by the philharmonic.

Let us consider in more detail how to organize Event-marketing - promotion of goods (services, brands) by creating and holding special events (Table 5).

\section{Application of modern creative types of marketing communications as illustrated by the philharmonic}

Table 4

\begin{tabular}{|c|c|c|c|c|}
\hline $\begin{array}{l}\text { Type of } \\
\text { marketing } \\
\text { communi- } \\
\text { cations }\end{array}$ & An example of application & Advantages & Disadvantages & Costs \\
\hline 1 & 2 & 3 & 4 & 5 \\
\hline $\begin{array}{c}\text { Art - } \\
\text { marketing }\end{array}$ & $\begin{array}{l}\text { Before the scheduled arrival of the stars, } \\
\text { place in the Internet (e.g. Facebook), } \\
\text { information about competition for the } \\
\text { best performance of the cover version } \\
\text { (author's composition), which should be } \\
\text { posted on YouTube, with the subsequent } \\
\text { voting of the pages' participants. By the } \\
\text { results of the month, the video } \\
\text { composition, which gained the largest } \\
\text { number of likes, receives prize tickets for } \\
\text { the concert of the singer, a singer's } \\
\text { autograph and the right to get two more } \\
\text { tickets at half price }\end{array}$ & $\begin{array}{l}\text { 1) Reaching } \\
\text { large audience } \\
\text { of students and } \\
\text { young people; } \\
\text { 2) "The word of } \\
\text { mouth" } \\
\text { advertising; } \\
\text { 3) minimum } \\
\text { costs }\end{array}$ & $\begin{array}{l}\text { 1) Not } \\
\text { interesting for } \\
\text { all young } \\
\text { people; } \\
\text { 2) Only those } \\
\text { persons who } \\
\text { can play the } \\
\text { musical } \\
\text { instrument } \\
\text { will be able to } \\
\text { participate }\end{array}$ & $\begin{array}{l}\text { Purchase of two } \\
\text { tickets, } \\
\text { compensation of } \\
\text { the discount; } \\
\text { the work of the } \\
\text { orchestra } \\
\text { administrator } \\
\text { with the Internet } \\
\text { resources }\end{array}$ \\
\hline $\begin{array}{l}\text { Guerrilla } \\
\text { marketing }\end{array}$ & $\begin{array}{l}\text { Paint piano keys of white and black } \\
\text { colour on the steps of large shopping } \\
\text { complexes. At the end, put an inscription } \\
\text { "jazz" and the official site of the touring } \\
\text { orchestra. }\end{array}$ & $\begin{array}{l}\text { 1) Reaching } \\
\text { large audience } \\
\text { of all ages; } \\
\text { 2) May be } \\
\text { remembered due } \\
\text { to an emotional } \\
\text { burst }\end{array}$ & $\begin{array}{l}\text { 1) Possibility } \\
\text { of being fined; } \\
\text { 2) Due to such } \\
\text { aggressive } \\
\text { advertising } \\
\text { may not be } \\
\text { accepted by } \\
\text { the local } \\
\text { orchestra, } \\
\text { individual } \\
\text { local residents }\end{array}$ & $\begin{array}{l}\text { Aerosol ink } \\
\text { cartridge, } \\
\text { work of the } \\
\text { artist }\end{array}$ \\
\hline $\begin{array}{c}\text { Entertainment- } \\
\text { marketing }\end{array}$ & $\begin{array}{l}\text { Taking advantage of the opportunity of a } \\
\text { planned city event (e.g. City Day) to play } \\
\text { a free concert in the open public space. } \\
\text { This event is announced for a month in } \\
\text { the Internet and printed media (at the } \\
\text { expense of the Ministry of Culture). }\end{array}$ & $\begin{array}{l}\text { 1) Has a long- } \\
\text { lasting effect - } \\
\text { (begins long } \\
\text { before the event } \\
\text { in the } \\
\text { announcements } \\
\text { and posters); }\end{array}$ & $\begin{array}{l}\text { Practically no } \\
\text { disadvantages }\end{array}$ & $\begin{array}{l}\text { Making and } \\
\text { printing } \\
\text { invitations; } \\
\text { several } \\
\text { volunteers for } \\
\text { the distribution }\end{array}$ \\
\hline
\end{tabular}


Table 4 continuation

\begin{tabular}{|c|c|c|c|c|}
\hline 1 & 2 & 3 & 4 & 5 \\
\hline & $\begin{array}{l}\text { During the concert, invitations for the } \\
\text { next concert are being distributed with } \\
\text { the possibility of winning the main } \\
\text { prize - two tickets to the concert with the } \\
\text { participation of a world-class star. All the } \\
\text { participants who received the invitation } \\
\text { must register in the official group and } \\
\text { follow the results of the lottery. }\end{array}$ & $\begin{array}{l}\text { 2) Large } \\
\text { audience } \\
\text { coverage; } \\
\text { 3) Minimum } \\
\text { costs }\end{array}$ & & $\begin{array}{l}\text { of invitations; } \\
\text { the cost of two } \\
\text { tickets }\end{array}$ \\
\hline $\begin{array}{l}\text { Event- } \\
\text { marketing }\end{array}$ & $\begin{array}{l}\text { In the hall of the regional philharmonic to } \\
\text { hold an evening devoted to fans of jazz } \\
\text { music for regular visitors. Along the hall } \\
\text { to set tables with treatments: fruit, } \\
\text { cookies, tea, coffee, desserts. The "live } \\
\text { music" is playing during the whole } \\
\text { evening with short breaks. During the concert, } \\
\text { the listeners can enjoy music, make new } \\
\text { acquaintances and dance. All attendees will } \\
\text { be given an invitation to a future concert and } \\
\text { an opportunity to purchase a subscription at } \\
\text { an affordable price. }\end{array}$ & $\begin{array}{l}\text { 1) Acquaintance, } \\
\text { communication } \\
\text { and further } \\
\text { "word of } \\
\text { mouth" } \\
\text { advertising; } \\
\text { 2) the reach of } \\
\text { the able-to-pay } \\
\text { audience } \\
\text { 3) small } \\
\text { expenses }\end{array}$ & $\begin{array}{l}\text { 1) Paid } \\
\text { participation } \\
\text { (visitors are } \\
\text { likely to cover } \\
\text { food and drink } \\
\text { costs); } \\
\text { 2) small } \\
\text { coverage of } \\
\text { new audience }\end{array}$ & minimal \\
\hline
\end{tabular}

Source: compiled by the authors

Table 5

Organization of Event-marketing and description of its main stages

\begin{tabular}{|l|l|l|}
\hline \multicolumn{1}{|c|}{ The main stages } & \multicolumn{1}{|c|}{ Components of the stages } & \multicolumn{1}{c|}{ Characteristic } \\
\hline Event planning & $\begin{array}{l}\text { Determining the tasks of the event } \\
- \text { developing the event concept } \\
- \text { choosing a location } \\
- \text { selecting contractors and signing contracts } \\
\text { with them } \\
- \text { creating a budget for the event } \\
- \text { developing the event scenario } \\
- \text { announcing and promoting the event }\end{array}$ & $\begin{array}{l}\text { At this stage, it is necessary to understand } \\
\text { clearly, why this event is necessary, what tasks } \\
\text { need to be solved, what results are to be } \\
\text { achieved. The structure of the event, its } \\
\text { content and effectiveness depend on this } \\
\text { understanding }\end{array}$ \\
\hline Organizing the event & $\begin{array}{l}\text { Having a general rehearsal } \\
- \text { Methods of coordinating activities } \\
\text { (work with scenario) }\end{array}$ & $\begin{array}{l}\text { The development of the event is the work on } \\
\text { creating a consistent algorithm of action } \\
\text { capable of effectively solving the task. } \\
\text { The products of the event development are a } \\
\text { directing script and a complete package of } \\
\text { documents necessary for the event. }\end{array}$ \\
\hline $\begin{array}{l}\text { Evaluating the event } \\
\text { effectiveness }\end{array}$ & $\begin{array}{l}\text { Investigating: } \\
- \text { whether the number of visitors increased; } \\
- \text { what reviews were given; } \\
- \text { whether the event was justified in terms } \\
\text { of invested expenses }\end{array}$ & $\begin{array}{l}\text { At this stage, it is necessary to examine clearly } \\
\text { whether the goals were achieved, what the } \\
\text { difficulties were and what main conclusions } \\
\text { could be made. }\end{array}$ \\
\hline
\end{tabular}

Source: compiled by the authors

So, in order to correctly formulate the task of creating an event, you should follow the same rules, which are applied in the creation of all other promotional products:
1. Identify (develop, invent) the main message of the event.

2. Clearly describe the target audience of the event. It is necessary to learn everything 


\section{Marketing communications as a necessary prerequisite for efficient work of a philharmony}

possible about it, up to musical and culinary preferences.

3. Identify and describe what kind of the audience response and other outcomes of the event are expected. (If the expected event outcomes can be described only as "good spirits" and "positive emotions", then the event does not make sense from the point of view of the marketing and PR strategy of the organization. Even the philharmonic marketing service is aimed, first of all, to increase the number of visitors and the sales volume.)

4. The event should be an integral part of the overall marketing strategy of the organization of culture and arts.

Today, standard use of marketing means and tools is ineffective. The greatest success is achieved by those organizations whose marketing is non-standard, creative, causing positive emotions, being surprising for the organisation's potential customers. The same applies to the philharmonic. The audience is not interested in hanged posters and stacks of flyers at the box office of an artistic organization; it awaits new creative solutions and innovative presentations of cultural products. In domestic cultural and artistic organizations, such modern tools of marketing communications are seldom. Therefore, we recommend borrowing foreign experience. For example, The Guardian has a network for professionals in the field of culture, one of the sections of which is devoted to communications [17]. Creative people and artists in the field of culture and arts share their own experiences, describe experiments and express non-standard ideas. In this regard, the experience of the worldclass chamber orchestra Manchester Camerata is very interesting for a philharmonic. This orchestra "redefined what an orchestra can do" and changed the strategy and vision of what an orchestra exists for, which audience it can address and what values it is guided by. As a result, it can perform in different formats: as a small orchestra (for small events it can offer something like solo serenades), as a classic orchestra (quintets for a large number of listeners) or as string quartets, which are perfect for more intimate occasions and create a more stylish atmosphere. And for large-scale shows, they can offer a full orchestra with a very wide range of repertoire - from standard classical musical compositions to cinema music, like the James Bond themed evening [18]. Thus, this orchestra is very flexible in promoting its cultural products and attracting the maximum number of viewers.

\section{Conclusions}

In the present difficult period, when military actions and constant conflicts are taking place in our country, culture is what can create the foundation for the formation of a healthy society.

Cultural and artistic organizations and philharmonic in particular, operate in conditions of instability, great competition and uncertainty. Their success depends directly on the number of visitors. Thus marketing communications play an extremely important role in attracting potential consumers of cultural products and services, enhancing profitability of cultural and artistic organizations, the philharmonic in particular.

The difficulty in promoting arts services of a philharmonic is due to lack of funds for marketing. Therefore, to obtain funds for implementing marketing ideas we propose to use new financial technologies - fundraising and crowdfunding.

Every year the interest in modern marketing communications tools grows. The study found that Guerrilla marketing and Art-marketing are not suitable in case of a philharmonic because of their "aggressive" way of promotion and possible problems with obtaining permission, while Entertainment-marketing and Event-marketing are recommended for use in the philharmonic.

\section{Prospects for further research}

Further research will deal with more detailed study of the effectiveness of marketing activities for promoting goods and services of cultural and artistic organizations.

\section{References}

1. Kotler, F. \& Sheff J. (2004) Vse bilety prodany. Strategii marketinga ispolnitelskih iskusstv [All tickets are sold. Strategies for the Marketing of Performing Arts],. Moscow: Izd-vo "KlassikaXXI" [in Russian].

2. Colber, F. (2004) Marketynh u sferi kultury ta mystetstv [Marketing in the field of culture and arts] Lviv, [in Ukrainian].

3. Borisova, T. (2015) Marketynh nekomertsiinykh orhanizatsii u rozrizi sfer diialnosti : teoriia $i$ 


\section{O. Karyy, K. Protsak, O. Prosovych}

praktyka [Marketing of nonprofit organizations in terms of areas of activity: theory and practice] Ternopil: Aston [in Ukrainian].

4. Kuchina, N. I. (2015) Rol marketynhu v diialnosti orhanizatsii sotsiokulturnoi sfery [The role of marketing in the activities of organizations of the socio-cultural sphere] Culture of Ukraine. Series: Culturology. 48, 128-138. [in Ukrainian].

5. Larina, A. V. Osoblyvosti reklamnoho prosuvannia kulturnoho produktu $v$ systemi marketynhu sotsialno-kulturnoi sfery [Features of advertising promotion of a cultural product in the marketing system of socio-cultural sphere] APRIORI. Series: Humanities. 4, 1-12. [in Ukrainian].

6. Rozhok O. V. (2016) Kulturolohichnyi pidkhid u doslidzhenni suchasnykh upravlinskykh stratehii u kulturi (na prykladi filarmonii yak kulturnomystetskoho seredovyshcha) [Cultural approach in the study of modern management strategies in culture (for example, philharmonic as a cultural and arts environment)] Journal of the National Music Academy of Ukraine named after P. I. Tchaikovsky. 1, 155-162. [in Ukrainian].

7. Sytnik, O. G. (2012) Marketynhovi komunikatsii v teatralnii diialnosti: zastosuvannia ta vprovadzhennia PR-tekhnolohii [Marketing communications in the theatrical activity: application and implementation of PR-technologies] Culture of Ukraine. 39, 174181. [in Ukrainian].

8. Soloveichyk, V. A. \& Mogylova, Yu. (2016) Osoblyvosti rozvytku marketynhu u sferi kultury ta mystetstv [Features of marketing development in the field of culture and arts] Bulletin of the Odessa National University. Series: Economics 21, issue 6, 106-109. [in Ukrainian].

9. Stepanov V. Yu. (2012) Informatsiinyi marketynh u sferi kultury [Information marketing in the field of culture] Culture of Ukraine. 39, 39-46. [in Ukrainian].

10. Strogal, M. O. (2016) Uprovadzhennia mekhanizmu fandreizynhu $v$ sferu kultury Ukrainy [Implementation of fundraising mechanism in the sphere of culture of Ukraine] International Bulletin: Culturology. Philology. Musicology. 1, 131-136. [in Ukrainian]
11. Statystychnyi biuleten Derzhavnoi sluzhby statystyky [Statistical bulletin of the State Statistics Service]/ [Electronic resource]. Access mode: http://www.ukrstat.gov.ua/druk/publicat/Arhiv_u/1 5/Arch_zkm_bl.htm [in Ukrainian].

12. Kotenko, N. V., Serdyuk, S. G., \& Saltykova, G. V. (2015) Marketynhovi instrumenty upravlinnia finansuvanniam ta prosuvanniam posluh neuriadovykh orhanizatsii [Marketing Tools for Managing Funding and Promotion of NonGovernmental Services] Marketing and Management Innovation, 4, 20-33. [in Ukrainian].

13. Bakalchuk, V. \& Kuzmuk, O. Zarubizhnyi dosvid zaluchennia pozabiudzhetnykh koshtiv na rozvytok kultury : analit. zap. [Foreign experience of attracting extrabudgetary funds for cultural development: analysis notes] [Electronic resource] Izd-vo Institute of Strategic Research under the President of Ukraine. - Access mode: http://old.niss.gov.ua/Monitor/February/2.htm [in Ukrainian].

14. Poiasniuvalna zapyska do proektu Kodeksu zakoniv Ukrainy pro kulturu [EXPLANATORY NOTE to the draft Code of Laws of Ukraine on Culture] [Electronic resource]. Access mode: w1.c1.rada.gov.ua/pls/zweb2/webproc34?id $=\& p f 3$ 511=15098\&pf35401 [in Ukrainian].

15. Oklander T. O. (2011) Innovatsiini metody vplyvu na spozhyvachiv: aromamarketynh [Innovative methods of influence on consumers: aromamarketing] Marketing and management of innovations. 3, 97-101. [in Ukrainian].

16. Melnyk Yu. M., Sager L. Yu., L. Yu., \& Cherkas I. Yu. Transformatsiia marketynhovykh komunikatsii: netradytsiini vydy [Transformation of marketing communications: non-traditional species] Bulletin of the Khmelnitsky National University. Economic sciences 2 (1), 164-168. [in Ukrainian].

17. The Guardian Advice and ideas for arts marketing, press, PR and promotion. Access Mode: https://www.theguardian.com/culture-

professionals-network/communications United Kingdom, [in England]

18. Manchester Camerata. Access Mode: http://www. manchestercamerata.co.uk/the-orchestra/hire-theorchestra Manchester [in England] 